\title{
Quantitative risk assessment of hypothetic investment portfolio: the case of the Baltic States
}

\begin{abstract}
This study examines the performance of 5 Value-at-Risk (VaR) methods in the context of investment portfolio management. A comparative analysis reveals that testing methods give similar risk assessment values and the choice of proper time horizon and observation period plays a more important role than the choice of method.
\end{abstract}

Keywords: risk assessment, VaR methods, investment portfolio, Baltic stock market.

Straipsnyje analizuojama penkių VaR metodų taikymo rezultatai investicinio portfelio valdymo kontekste. Lyginamoji analizè parodè, kad atlikti bandymai duoda panašias rizikos vertinimo vertes ir tinkamo laiko horizonto bei stebėjimo laikotarpio pasirinkimas vaidina svarbesnị vaidmenį nei taikomo metodo parinkimas.

Raktiniai žodžiai: rizikos vertinimas, VaR metodai, investicijų portfelis, Baltijos šalių akcijų rinka.

JEL Classifications: G11/G17.

\section{Introduction}

Financial institutions, insurance companies, private investors and other financial market participants nowadays face the challenge of evaluating the potential loss of transactions, especially in light of the recent financial crisis that showed what can happen as a result of poor risk management policy. One of the most important applications of risk assessment is the investment portfolio theory; the risk assessment has been introduced in 1952 in the formation of the modern portfolio theory. Risk assessment methods since then have been developed rapidly and it is important to understand the relationship between the specific applications of the Baltic stock markets.

Currently, there are several approaches to risk assessment and risk concept in general, which are described in the literature. In practice, unfortunately, the risk assessment methods that are not based on theory are used more commonly. The reasons for this are complexity and shortcomings of theoretically based risk assessment methods. It should be noted that the problem stems

Ramona RUPEIKA-APOGA - Dr. of economics, University of Latvia. Address: Aspazijas 5, Riga, Latvia; phone: 00371 67034625; e-mail: rr@lu.lv.

Roberts NEDOVISS - bachelor of economics, University of Latvia. Address: Aspazijas 5, Riga, Latvia; phone: 00371 67034625; e-mail: roberts_nedoviss@inbox.lv. 
from the lack of dedicated software that can be used in risk assessment. Excel environment is unable to process huge amount of data to be analysed by assessing the risks. Additionally, the statistical packages SPSS and Eviews have no built-in function for risk assessment. Thus, to evaluate risk we need to design individual programs, which may require large funds.

There are numerous complex barriers to effective risk assessment. First of all, there are no single unambiguous methods of how to measure risk, as some methods may produce different results. Secondly, each method has its own shortcomings. The scientific problem of the research is to find risk assessment methods that can be used in investment portfolio management.

Nowadays, Value-at-Risk holds a special place in the financial sector - it is used almost everywhere. Value-at-Risk (VaR) is defined as a portfolio loss for a given horizon that should only be exceeded at a given target probability. $\mathrm{VaR}$ is particularly important because it is used to calculate the market risk component of regulatory capital under the Basel Committee and it is one of the most applied in portfolio theory of investment, financial control and financial reporting as well.

As a misleading VaR estimate can lead to bad judgement on portfolio risk and, consequently, to bad investment decisions, there is a need for an examination of VaR applications in the context of Baltic stock market investors.

The object of this paper is the risk assessment methods in the context of investment portfolio management.

In this research the authors aim to design the hypothetical portfolio from the Baltic States shares and to find the best tool for risk assessment within the VaR methodology. The study estimates five VaR risk assessment methods to measure risk for different horizons and observation frequency during the period from 2000 to 2012.

To achieve our purpose the following tasks were conducted:

1. to identify the main methods of risk assessment;

2. to construct investment portfolio from Baltic stock market shares;

3. to examine the performance of 5 Value-at-Risk (VaR) methods in the context of investment portfolio management: historical, delta-gamma-normal, deltagamma-stable, Cornish-Fisher and Monte-Carlo;

4. to offer appropriate investment horizons and frequency of observation periods;

5. to make conclusions and to put forward offers relevant to investors looking for a satisfactory risk assessment tool on the basis of the authors' findings.

The research methodology used in this paper starts with a literature review in order to highlight the difficulties faced by investors in choosing the optimal risk assessment method. During development of the paper the generally accepted qualitative and quantitative methods of economic research were used including Value-at-Risk (VaR) methods to measure risks for different horizons and by testing different observation periods of a hypothetical investment portfolio. Then, their out-of-sample predictive abilities are formally assessed using the unconditional coverage test.

For practical implementation of Valueat-Risk methods the authors used $M$. Taqqu and B. Bradley (2001), P. Jorion (2001) and P. Embrechts et al. (2005) works.

The data set is based on the firms' stock quotes. It contains prices of all 36 firms that 
were publicly listed on Nasdaq OMX Baltic Stock Exchange official list for the period spanning 2000 to 2012 . The analysis conducted in this paper is based on data and statistics provided mainly by Nasdaq OMX Baltic Stock Exchange.

\section{Literature review and hypotheses}

Risk assessment consists of an objective evaluation of risk in which assumptions and uncertainties are clearly considered and presented. Part of the difficulty in risk management is that measurement of both of the quantities in which risk assessment is concerned - potential loss and probability of occurrence - can be very difficult to measure. The chance of error in measuring these two concepts is large. Methods for assessment of risk may differ between industries and whether it pertains to general financial decisions or environmental, ecological, or public health risk assessment. As was mentioned previously, Value-atRisk is one of the most used risk measure methods.

VaR can be estimated either parametrically (for example, variance-covariance VaR or delta-gamma VaR) or nonparametrically (for example, historical simulation VaR or resampled VaR). Nonparametric methods of VaR estimation are discussed in N. Markovich (2007) and S. Y. Novak (2011).

Historical method or Historical simulation (HS) method is one of the best-known and most widely used methods to obtain an empirical distribution of profits and losses, from which various risk statistics can be estimated: VaR, conditional expected shortfall, and others. The historical method of VaR estimation simply re-organizes actual historical returns, putting them in order from worst to best and choosing the a return, where $\alpha$ is VaR target probability. It is assumed in the method that history will repeat itself, from a risk perspective. Historical simulation in finance's VaR analysis is a procedure for predicting value at risk by constructing the cumulative distribution function of assets returns over time and simulating new sample from it.

The main pros of Historical methods are that these methods do not assume any distribution on the asset returns and it is relatively easy to implement (e.g., Lambadiaris et al., 2003; Jorion, 2006). However, there are some cons of historical methods:

- it imposes a restriction on the estimation assuming asset returns are independent and identically-distributed;

- it applies equal weight to all returns of the whole period and this is inconsistent with the nature where there is diminishing predictability of data that are further away from the present.

These two disadvantages lead researchers to further develop other VaR methods as non-parametric, semi-parametric and parametric models (e.g., Kuester et al., 2006).

Additionally, a lot of researchers (Artzner et al., 1999; Bertsimas et al., 2000; Embrechts et al., 2000; Pflug, 2000; Tasche, 2000; Uryasev, 2000), practitioners and regulators (Yamai, Yoshiba, 2001) began to criticise $\mathrm{VaR}$ as a risk measure method and to look for better solutions and "improved" methods.

Value-at-Risk is defined as a portfolio loss for a given horizon that should only be exceeded at a given target probability. It follows from the definition that the horizon choice plays special role in risk assessment. By author thoughts, the so-called time horizon right choice, that is, to choose 
the frequency of observations and the duration of forecasting period, is one of the main problems in applying VaR methods. In other words - what is the type of data used: minutes, hours, days, or months? And is it possible to use the Value-at-Risk value, which is calculated for the one-time horizon, to calculate the Value-at-Risk for a different time horizon? How to choose the data frequency to Value-at-Risk givedate (actual) risk assessment?

Observation frequency. In particular, it has been documented extensively that, at frequencies higher than a month, the distribution of the returns of most financial assets, such as stocks or exchange rates, is characterized by pronounced departures from Gaussianity. Most notably, the empirical return distributions tend to be leptokurtic, that is, they are more peaked and fatter tailed than the Gaussian distribution with the same variance, and there can be non-negligible deviations from symmetry as well (Haas, Pigorsch, 2009; Haas, 2009). Moreover, returns are not independently distributed but, as already observed by $\mathrm{B}$. Mandelbrot (1963), characterized by pronounced volatility clustering, meaning that "large [price] changes tend to be followed by large changes - of either sign - and small changes tend to be followed by small changes".

Horizon periods. It is not clear that best-performing VaR models at very short horizons can continue their success over longer horizons, as returns over different horizons do not present the same properties.

For example, compared with daily returns, monthly returns follow a distribution with less asymmetry, and fat tails are less autocorrelated, resulting in a smaller sample of observations for precise estimation (Chretien et al., 2010). Such characteristics could work against difficult-to-estimate VaR models with complex conditional specification of the return process.

M. Guidolin and A. Timmermann (2006) present some related evidence by characterising the term structure of VaR measures for horizons of up to 24 months. They documented large variations in both levels and shapes of term structures across different approaches. They also found that the best models in terms of predictive performance may be asset and horizon-specific and depend on how far out in the tails one measures risk.

There are no unequivocal answers to these questions. It is proposed to select the time horizon for Value-at-Risk estimation according to its purpose: for example, if the Value-at-Risk is calculated to estimate the exchange rate risks in FOREX (or financial portfolio), then it would be logical to use very small Value-at-Risk horizons, but, if the Value-at-Risk is used for bank credit risk assessment, the horizon should be longer. If the Value-at-Risk is calculated for company's own needs, then, of course, the company can decide how to calculate it, but the reference often required is 10 day Value-at-Risk calculation. These problems are widely described by J. P. Morgan (1996).

For practical implementation of Valueat-Risk methods the authors used $\mathrm{M}$. Taqqu and B. Bradley (2001), P. Jorion (2001) and P. Embrechts et al. (2005) works.

Practical VaR measure implementation assumes a statistical model for the data. Different underlying models lead to different VaR estimates. Our first hypothesis concerns the robustness of VaR methods towards underlying models.

H1: VaR methods of risk assessment give similar results.

Long term risk estimates are often 
needed for practical purposes. Our second hypothesis concerns risk aggregation in time

H2: Precise prediction of portfolio risk using VaR methods is only possible for short horizons.

Large data samples often provide more opportunities for statistical inference, making estimates more precise. Our third hypothesis is

H3: The longer the observation period the better predictive abilities.

\section{Methodology}

\section{Sample and data collection}

The data set is based on the company's stock quotes. It contains prices of all 36 companies that were publicly listed on Nasdaq OMX Baltic Stock Exchange official list for the period spanning 2000 to 2012. The data were taken from the Nasdaq website.

The construction of portfolio requires choosing a period in which the parameters (such as return on assets, VAR (Value-atRisk)) will be evaluated. On the one hand, the period should be long enough to return variance estimations to give significant results, on the other hand, assets must be static. The problem with the data is that not all of the company's shares were traded in the 2000; some companies entered the market only in 2007 or in 2010. A portfolio for 2011 will be created to solve this problem, at the time other data will be used for the tests.

\section{Portfolio selection of the optimal weight}

One of the possible approaches to choose the optimal weights of the portfolio is
Markowitz portfolio theory. As portfolio is a selected combination of assets, the evaluation of portfolio risk could be measured by disaggregating the portfolio returns into its underlying asset returns.

By fixing the volatility or return, it's possible to minimize first parameter or to maximize the second parameter respectively and get optimal assets weights in portfolio.

Risk minimization at a fixed rate of return:

RISK $=\sum_{i=1 . i=1}^{n} w_{i} w_{i} S_{i, i} \rightarrow \min .,(1)$

$\left\{\begin{array}{c}\overline{i=1} \\ w_{i} \geq 0, i=1, \ldots, n,\end{array}\right.$

where, $R_{i}-\mathrm{m}$ return of $\mathrm{i}$-asset; $S_{i, j}-i$ and $j$ assets covariance (dispersion, if $i=j$ ).

Another argument for the use of the Markowitz approach to portfolio selection is as follows: if Value-at-Risk is used instead of volatility, which is calculated by VaR delta- gamma-normal method, portfolio weights remain the same:

$\operatorname{RISK}=\operatorname{VaR}(a) \rightarrow \min$.

$\left\{\begin{array}{l}\sum_{i=1}^{n} w_{i} R_{i}=R_{\text {fiks }}, \\ w_{i} \geq 0, i=1, \ldots, n,\end{array}\right.$
$\operatorname{VaR}(\alpha)=R_{\text {port }}+S_{\text {port }} F^{-1}(\alpha)=$
$=\sum_{i=1}^{n} w_{i} R_{i}+\sum_{i=1, j=1}^{n} w_{i} w_{j} S_{i, j} F^{-1}(\alpha)$.

In this expression, $F^{-1}(a)$ is a constant, $R_{\text {port }}=\sum w_{i} R_{f i}=R_{\text {fiks }}$ is fixed by the conditions. These constants will not affect the weights, that is, the $\operatorname{VaR}(\alpha)$ reaches a 
Ljung-Box test p-values of different companies' logarithmic returns (fragment)

\begin{tabular}{|l|c|c|c|c|c|c|}
\hline \multicolumn{1}{|c|}{ Number of lags } & APG1L & CTS1L & LDJ1L & OEG1T & SAB1L & UTR1L \\
\hline 1 & 0.949 & 0.722 & 0.645 & 0.096 & 0.602 & 0.130 \\
\hline 5 & 0.486 & 0.348 & 0.557 & 0.189 & 0.307 & 0.095 \\
\hline 8 & 0.567 & 0.234 & 0.637 & 0.192 & 0.390 & 0.065 \\
\hline 15 & 0.214 & 0.559 & 0.781 & 0.344 & 0.531 & 0.149 \\
\hline 20 & 0.125 & 0.380 & 0.808 & 0.196 & 0.279 & 0.107 \\
\hline
\end{tabular}

Results: the hypothesis of the independent distribution of the data cannot be rejected, that allows us to use data to consistently estimate asset returns.

Fragment of correlation matrix between the companies' assets

Table 2

\begin{tabular}{|l|c|c|c|c|c|c|c|c|c|}
\hline & APG1L & ARC1T & BLT1T & CTS1L & EEG1T & GRD1R & GRG1L & HAE1T & IVL1L \\
\hline APG1L & 1.000 & 0.275 & 0.285 & 0.650 & 0.354 & 0.143 & 0.554 & 0.318 & 0.545 \\
\hline ARC1T & 0.275 & 1.000 & 0.180 & 0.187 & 0.312 & 0.000 & 0.191 & 0.322 & 0.232 \\
\hline BLT1T & 0.285 & 0.180 & 1.000 & 0.251 & 0.258 & -0.010 & 0.248 & 0.177 & 0.311 \\
\hline CTS1L & 0.650 & 0.187 & 0.251 & 1.000 & 0.361 & 0.194 & 0.608 & 0.300 & 0.642 \\
\hline EEG1T & 0.354 & 0.312 & 0.258 & 0.361 & 1.000 & 0.059 & 0.320 & 0.424 & 0.269 \\
\hline GRD1R & 0.143 & 0.000 & -0.010 & 0.194 & 0.059 & 1.000 & 0.065 & 0.113 & 0.175 \\
\hline GRG1L & 0.554 & 0.191 & 0.248 & 0.608 & 0.320 & 0.065 & 1.000 & 0.343 & 0.501 \\
\hline HAE1T & 0.318 & 0.322 & 0.177 & 0.300 & 0.424 & 0.113 & 0.343 & 1.000 & 0.253 \\
\hline IVL1L & 0.545 & 0.232 & 0.311 & 0.642 & 0.269 & 0.175 & 0.501 & 0.253 & 1.000 \\
\hline
\end{tabular}

Results: Positive correlation between portfolio assets is specific for small Baltic stock market and underlines the need for the use of risk assessment.

minimum at the same point where so does $\sum_{i, j} w_{i} w_{j} S_{i, j} \sum_{i, j} w_{i} w_{j} S_{i, j}$. But this means that the Markowitz approach and the VaR delta-gamma-normal method give the same weights.

\section{Estimation of portfolio parameters}

Before the estimation of parameters it is necessary to analyse statistical characteristics of assets. The stationarity of the data was checked by graphical evaluation of autocovariation (and partial autocovariation) function, and by Ljung-Box test, thus enabling the use of usual estimates of returns (see Table 1).

The dependence structure between different assets was evaluated by covariance matrix(see Table 2). It is known that negative dependence between returns of different assets leads to greater opportunities of diversification of the risks in the portfolio. In its turn, diversification leads to the minimization of the portfolio's risk.

\section{Creation of hypothetic equity portfolio}

Portfolio selection of the optimal weight in accordance with Markowitz portfolio theory or delta-gamma-normal VaR is presented in Table 3.

Assets with weights smaller than 0.001 were not included in portfolio, as a result from 36 companies in portfolio remained only 11 companies' shares. 
A hypothetical portfolio's assets weights

\begin{tabular}{|l|c|}
\hline & W \\
\hline ARC1T & 0.077 \\
\hline BLT1T & 0.147 \\
\hline GRD1R & 0.190 \\
\hline LES1L & 0.052 \\
\hline LNA1L & 0.087 \\
\hline LNR1L & 0.149 \\
\hline LSC1R & 0.050 \\
\hline RSU1L & 0.074 \\
\hline SAF1R & 0.128 \\
\hline UKB1L & 0.026 \\
\hline UTR1L & 0.020 \\
\hline
\end{tabular}

\section{Empirical results}

\section{Estimation of the risk assessment methods}

Table 4 reports the results of five VaR risk assessment methods, with $1 \%$ target probability for each asset of portfolio as well as for all portfolios. The predicted logarithmic returns are shown. To get the predicted VaR values one should take the exponential of the logarithmic return and then multiply it by the last price of the asset. The advantage of leaving the logarithmic returns, but not the values of the assets, is the ability of comparing the performance of different assets.

All methods preserve the risk structure of the portfolio: more risky assets from one method's perspective tend to stay risky when evaluated by other methods. Different estimation methods also give rather similar quantitative results. It is obvious that delta-gamma-stable VaR methods give risk estimates that are many times greater than other methods. The reason for this lies in the heavy-tailedness of the stable distributions, which may lead to the over-assessment of the risk exposure.

Cornish-Fisher VaR estimates give the same results as delta-gamma-normal VaR. The cause of this is that Cornish-Fisher expansion gives the approximation of the distribution with higher moments ( $3^{\text {rd }}$ and $4^{\text {th }}$ in our case), but $3^{\text {rd }}$ and $4^{\text {th }}$ moments of the distribution of the logarithmic returns of the portfolio securities are negligible.

Another important aspect of risk

\section{Results of Value-at-Risk risk assessments methods}

Table 4

\begin{tabular}{|l|c|c|c|c|c|}
\hline \multicolumn{1}{|c|}{$\boldsymbol{\alpha}=\mathbf{0 . 0 1}$} & Historical & $\begin{array}{c}\text { Delta-gamma- } \\
\text { normal }\end{array}$ & $\begin{array}{c}\text { Delta- } \\
\text { gamma-stable }\end{array}$ & VaR-CF & $\begin{array}{c}\text { Monte-Carlo } \\
\text { normal }\end{array}$ \\
\hline ARC1T & 0.095717 & 0.080297 & 1.14688 & 0.080297 & 0.082504 \\
\hline BLT1T & 0.085175 & 0.085272 & 1.231992 & 0.085272 & 0.085267 \\
\hline GRD1R & 0.061805 & 0.054285 & 0.764794 & 0.054285 & 0.054 \\
\hline LES1L & 0.07776 & 0.055291 & 0.783252 & 0.055291 & 0.05514 \\
\hline LNA1L & 0.067995 & 0.051215 & 0.717188 & 0.051215 & 0.052181 \\
\hline LNR1L & 0.058061 & 0.062216 & 0.879224 & 0.062216 & 0.062322 \\
\hline LSC1R & 0.065303 & 0.05345 & 0.741418 & 0.05345 & 0.054716 \\
\hline RSU1L & 0.036951 & 0.041667 & 0.587844 & 0.041667 & 0.041598 \\
\hline SAF1R & 0.071049 & 0.061344 & 0.867949 & 0.061344 & 0.061696 \\
\hline UKB1L & 0.059662 & 0.051732 & 0.74485 & 0.051732 & 0.051126 \\
\hline UTR1L & 0.124277 & 0.102575 & 1.428982 & 0.102575 & 0.100245 \\
\hline Portfolio & 0.2303818 & 0.297199 & 2.691401 & 0.297199 & 0.026053 \\
\hline
\end{tabular}


assessment methods is how the estimates incorporate the dependence structure of the data, which in its turn influence the risk of the overall portfolio. Dealing with the assessment of the dependence structure, our study shows the incoherence of Value-at-Risk measure in aggregating portfolio risk of individual assets: the portfolio risk is greater than the weighted sum of the portfolio assets risks except of Monte-Carlo normal estimation method. The essence of Monte-Carlo normal method is the drawing from data-fitted multivariate normal distributions and getting new sample data. Then inference is done based on the new sample. The nice symmetry properties of the normal distribution lead to the good risk assessment properties of the estimation method. The question is if the primal data had the said property.

\section{Test of VaR methods predictive abilities}

The discussion above is meant to provide some advice in interpretation of the obtained results. Next the authors check predictive abilities of VaR methods.

To determine the predictive ability of VaR methods, first of all, we need to estimate Bernoulli parameters for different time horizons and observation periods and, secondly to implement the unconditional coverage test.

\section{Estimates of VaR Bernoulli parameters for long time observation periods}

Table 5

\begin{tabular}{|l|c|c|c|c|c|}
\hline \multicolumn{5}{|c|}{ Observation period } & \multicolumn{5}{c|}{ Horizons (days) } \\
\hline 6 months & 1 & 5 & 10 & 15 & 22 \\
\hline Historical VaR & 0.795031 & 0.677019 & 0.614907 & 0.590062 & 0.559006 \\
\hline VaR delta-gamma-normal & 0.875776 & 0.832298 & 0.795031 & 0.78882 & 0.776398 \\
\hline VaR delta-gamma-stable & 1 & 1 & 1 & 1 & 1 \\
\hline VaR Cornish-Fisher normal & 0.875776 & 0.832298 & 0.795031 & 0.78882 & 0.776398 \\
\hline VaR Monte-Carlo normal & 0.782609 & 0.776398 & 0.78882 & 0.776398 & 0.7888 \\
\hline 4 months & 1 & 5 & 10 & 15 & 22 \\
\hline Historical VaR & 0.784431 & 0.634731 & 0.556886 & 0.520958 & 0.48503 \\
\hline VaR delta-gamma-normal & 0.856287 & 0.802395 & 0.766467 & 0.730539 & 0.706587 \\
\hline VaR delta-gamma-stable & 1 & 1 & 1 & 1 & 1 \\
\hline VaR Cornish-Fisher normal & 0.856287 & 0.802395 & 0.766467 & 0.730539 & 0.706587 \\
\hline VaR Monte-Carlo normal & 0.814371 & 0.820359 & 0.826347 & 0.820359 & 0.820359 \\
\hline 3 months & 1 & 5 & 10 & 15 & 22 \\
\hline Historical VaR & 0.788235 & 0.6 & 0.517647 & 0.482353 & 0.435294 \\
\hline VaR delta-gamma-normal & 0.841176 & 0.770588 & 0.729412 & 0.705882 & 0.682353 \\
\hline VaR delta-gamma-stable & 1 & 1 & 1 & 1 & 1 \\
\hline VaR Cornish-Fisher normal & 0.841176 & 0.770588 & 0.729412 & 0.705882 & 0.682353 \\
\hline VaR Monte-Carlo normal & 0.835294 & 0.829412 & 0.835294 & 0.835294 & 0.829412 \\
\hline 2 months & 1 & 5 & 10 & 15 & 22 \\
\hline Historical VaR & 0.803468 & 0.624277 & 0.520231 & 0.473988 & 0.410405 \\
\hline VaR delta-gamma-normal & 0.83237 & 0.734104 & 0.687861 & 0.641618 & 0.595376 \\
\hline VaR delta-gamma-stable & 1 & 1 & 1 & 1 & 1 \\
\hline VaR Cornish-Fisher normal & 0.83237 & 0.734104 & 0.687861 & 0.641618 & 0.595376 \\
\hline VaR Monte-Carlo normal & 0.867052 & 0.861224 & 0.862272 & 0.86043 & 0.85943 \\
\hline
\end{tabular}


Estimates of VaR Bernoulli parameters for short time observation periods

Table 6

\begin{tabular}{|l|c|c|c|c|}
\hline Observation period & \multicolumn{4}{|c|}{ Horizons (days) } \\
\hline 1 month & 1 & 5 & 10 & 15 \\
\hline Historical VaR & 0.863636 & 0.630682 & 0.517045 & 0.443182 \\
\hline VaR delta-gamma-normal & 0.903409 & 0.795455 & 0.721591 & 0.664773 \\
\hline VaR delta-gamma-stable & 1 & 1 & 1 & 1 \\
\hline VaR Cornish-Fisher normal & 0.903409 & 0.795455 & 0.721591 & 0.664773 \\
\hline VaR Monte-Carlo normal & 0.892045 & 0.886364 & 0.886364 & 0.892045 \\
\hline 3 weeks & 1 & 5 & 10 & \\
\hline Historical VaR & 0.949153 & 0.785311 & 0.649718 & \\
\hline VaR delta-gamma-normal & 0.943503 & 0.819209 & 0.717514 & \\
\hline VaR delta-gamma-stable & 1 & 1 & 1 & \\
\hline VaR Cornish-Fisher normal & 0.943503 & 0.819209 & 0.717514 & \\
\hline
\end{tabular}

In literature there is no single answer

optimal. This study will investigate risk asas to which observation period will be

Table 7

The upper limit of the confidence level of Value-at-Risk probabilities for long time observation periods

\begin{tabular}{|c|c|c|c|c|c|}
\hline \multirow{2}{*}{$\begin{array}{l}\text { Observation period } \\
6 \text { months }\end{array}$} & \multicolumn{5}{|c|}{ Horizons (days) } \\
\hline & 1 & 5 & 10 & 15 & 22 \\
\hline Historical VaR & 0.869042 & 0.762753 & 0.704124 & 0.680234 & 0.650036 \\
\hline VaR delta-gamma-normal & 0.936249 & 0.900795 & 0.869042 & 0.86365 & 0.852789 \\
\hline VaR delta-gamma-stable & 1 & 1 & 1 & 1 & 1 \\
\hline VaR Cornish-Fisher normal & 0.936249 & 0.900795 & 0.869042 & 0.86365 & 0.852789 \\
\hline VaR Monte-Carlo normal & 0.858232 & 0.852789 & 0.86365 & 0.852789 & 0.863633 \\
\hline \multicolumn{6}{|l|}{4 months } \\
\hline Historical VaR & 0.858457 & 0.721411 & 0.646311 & 0.610888 & 0.574999 \\
\hline VaR delta-gamma-normal & 0.919437 & 0.874077 & 0.842629 & 0.810409 & 0.788554 \\
\hline VaR delta-gamma-stable & 1 & 1 & 1 & 1 & 1 \\
\hline VaR Cornish-Fisher normal & 0.919437 & 0.874077 & 0.842629 & 0.810409 & 0.788554 \\
\hline VaR Monte-Carlo normal & 0.884363 & 0.889466 & 0.89454 & 0.889466 & 0.889466 \\
\hline \multicolumn{6}{|l|}{3 months } \\
\hline Historical VaR & 0.861131 & 0.687409 & 0.606803 & 0.571509 & 0.523755 \\
\hline VaR delta-gamma-normal & 0.906392 & 0.845607 & 0.808679 & 0.787179 & 0.76542 \\
\hline VaR delta-gamma-stable & 1 & 1 & 1 & 1 & 1 \\
\hline VaR Cornish-Fisher normal & 0.906392 & 0.845607 & 0.808679 & 0.787179 & 0.76542 \\
\hline VaR Monte-Carlo normal & 0.901474 & 0.896525 & 0.901474 & 0.901474 & 0.896525 \\
\hline \multicolumn{6}{|l|}{2 months } \\
\hline Historical VaR & 0.873751 & 0.709936 & 0.608593 & 0.562303 & 0.497408 \\
\hline VaR delta-gamma-normal & 0.898437 & 0.812246 & 0.769816 & 0.726431 & 0.682187 \\
\hline VaR delta-gamma-stable & 1 & 1 & 1 & 1 & 1 \\
\hline VaR Cornish-Fisher normal & 0.898437 & 0.812246 & 0.769816 & 0.726431 & 0.682187 \\
\hline VaR Monte-Carlo normal & 0.927102 & 0.92237 & 0.923224 & 0.921722 & 0.920906 \\
\hline
\end{tabular}


Table 8

The upper limit of the confidence level of Value-at-Risk probabilities for short time observation periods

\begin{tabular}{|c|c|c|c|c|}
\hline Observation period & \multicolumn{4}{|c|}{ Horizons (days) } \\
\hline 1 month & 1 & 5 & 10 & 15 \\
\hline Historical VaR & 0.923643 & 0.715072 & 0.604424 & 0.530045 \\
\hline VaR delta-gamma-normal & 0.955062 & 0.865988 & 0.799966 & 0.747319 \\
\hline VaR delta-gamma-stable & 1 & 1 & 1 & 1 \\
\hline VaR Cornish-Fisher normal & 0.955062 & 0.865988 & 0.799966 & 0.747319 \\
\hline VaR Monte-Carlo normal & 0.946308 & 0.941859 & 0.941859 & 0.946308 \\
\hline \multicolumn{4}{|l|}{3 weeks } & \\
\hline Historical VaR & 0.987459 & 0.856907 & 0.732901 & \\
\hline VaR delta-gamma-normal & 0.983761 & 0.886313 & 0.796016 & \\
\hline VaR delta-gamma-stable & 1 & 1 & 1 & \\
\hline VaR Cornish-Fisher normal & 0.983761 & 0.886313 & 0.796016 & \\
\hline
\end{tabular}

sessments for different time horizons and observation periods.

The results for their out-of-sample testing with Bernoulli parameters are shown in table 5 for long time observation periods and for short time periods in table 6 .

The Tables 4 and 5 show that VaR methods predictive abilities vary significantly from chosen horizons and the frequency of observation periods.

Most of the methods give the best prediction for shorter horizons and observation periods. The exception is the normal Monte-Carlo, which gives statistically significant results over a longer period. It turns out that the risk assessment of a larger number of data (longer observation period) does not give accurate results; conversely, it is better to use the short - up to one month - assessment periods.

Evaluation of risk is related to two problems: the risk could be underestimated or overestimated. The unconditional coverage test showed that greater part of the evaluation methods significantly underestimate the risk of the equity portfolio, since no method has achieved the $95 \%$ confidence level, except for historical and VaR deltagamma-normal methods for three weeks observation period and for 1-day horizon assessment.

Formula for confidence level is the following:

$I_{\beta}=\left(p-q_{\beta} \frac{\sqrt{p(1-p)}}{\sqrt{n}}, p+q_{\beta} \frac{\sqrt{p(1-p)}}{\sqrt{n}}\right)$,

where, $\beta$ is the normal distribution quantile.

The unconditional coverage test (see Tables 7 and 8) proved that statistically significant risk values can be obtained only for short observation periods and for short horizons. Conducted analysis rejected our hypothesis H3: the longer the observation period the better predictive abilities, but confirmed the hypothesis H2: precise prediction of portfolio risk using VaR methods is only possible for short horizons.

\section{Conclusions}

The study considers issues that are relevant for investors looking for a satisfactory risk assessment tool. A hypothetical portfolio from the Baltic States shares was selected as an investment object. To select the optimal 
portfolio weights the authors used Markowitz portfolio theory and VaR delta- gamma-normal method. After analysis, it was concluded that both methods offer the same assets' weights for the creation of a hypothetical portfolio. Before creation of the portfolio statistical characteristics of assets were analysed, using autocovariance and partial autocovariance tests; Ljung-Box independent distribution test; correlation matrix and variance analysis. As a result out of 36 firms that were publicly listed on Nasdaq OMX Baltic Stock Exchange official list for the period 2011, only 11 companies' shares were chosen. Conducted analysis shows existence of positive correlation between the assets that increases the overall risk of the portfolio and underlines the need for the use of risk assessment tools in the small Baltic stock market.

This paper studies the performance of 5 VaR methods of risk assessment: historical, delta-gamma-normal, delta-gammastable, Cornish-Fisher and Monte-Carlo. Further analysis of the empirical results determines that 4 of 5 methods give similar VaR values and essentially improve the risk structure of the portfolio: different evaluation methods tend to assess greater or smaller risk to the same assets. This confirms the hypothesis $\mathrm{H} 1$ : VaR methods of risk assessment give similar results.
The study implements the unconditional coverage test to assess the performance of the out-of-sample VaR predictions of the different methods and for different time horizons and observation periods. The analysis rejects our hypothesis $\mathrm{H} 3$ : the longer the observation period the better predictive abilities, but confirms the hypothesis $\mathrm{H} 2$ : precise prediction of portfolio risk using VaR methods is only possible for short horizons. The authors recommend using time horizon of 1 day and observation period of up to 1 month to measure risk of Baltic equity portfolio.

The current study is not free from limitations. Only 5 Value-at-Risk (VaR) methods in the context of investment portfolio management were used: historical, deltagamma-normal, delta-gamma-stable, Cornish-Fisher and Monte-Carlo, but it will be interesting to exam also other VaR methods and other risk assessment methods, especially some risk estimates based on parametric models that would give further inside into the empirical performance of VaR methods for the stock of Baltic companies. Future studies that replicate the current proposal, including panel data of companies listed on Nasdaq Stock market, may provide a more complete picture or add further dimensions to the current findings.

\section{References}

1. Artzner, P., Delbaen, F., Eber, J., Heath, D. (1999). Coherent Measures of Risk, Math, Fin. No. 9 (3), pp. 203-228.

2. Bertsimas, D., Lauprete, G. J., Samarov, A. (2000). Shortfall as a Risk Measure: Properties, Optimization and Applications. - Working paper, Sloan School of Management, MIT, Cambridge.

3. Chretien, S., Coggins, F., Trudel, Y. (2010). Performance of Monthly Multivariate Filtered Historical Simulation Value-at-risk // Journal of Risk
Management in Financial Institutions. Vol. 3 Issue 3, pp. 259-277.

4. Embrechts, P. (2000). Extreme Value Theory: Potential and Limitations as an Integrated Risk Management Tool. - Working paper, ETH Zurich. Internet access: <http://www.math.ethz. ch/embrechts/>, [accessed January 25, 2013].

5. Embrechts, P., McNeil, A., Frey, R. (2005). Quantitative Risk Management: Concepts, Techniques and Tools. - Princeton University 
Press, Princeton and Oxford, pp. 538. doi: 10.1198/jasa.2006.s156.

6. Guidolin, M., Timmermann, A. (2006). Term Structure of Risk under Alternative Econometric Specifications // Journal of Econometrics. Vol. 131, No. 1-2, pp. 285-308. doi: 10.2139/ ssrn.539842.

7. Haas, M. (2009). Value-at-Risk via Mixture Distributions Reconsidered // Journal of Applied Mathematics and Computation. Nr. 215, pp. 2103-2119.

8. Haas, M., Pigorsch, C. (2009). Financial Economics: Fat-tailed Distributions / in: B. Meyers (Ed.), Encyclopedia of Complexity and Systems Science. Vol. 4. doi: 10.1007/978-0-387-30440-3_204.

9. Hull, J., White, A. (1998). Incorporating Volatility Updating into the Historical Simulation Method for Value-at-risk // Journal of Risk. Fall. Vol. 1, No. 1, pp. 115-119.

10. Jorion, P. (2006). Value at Risk: The New Benchmark for Managing Financial Risk, 3rd ed. McGraw-Hill, New York, NY, pp. 262-265. doi: $10.1036 / 0071379215$.

11. Jorion, P. (2001). Value at Risk: the New Benchmark for Managing Financial Risk. - Donnelley and Sons Company, McGraw-Hill, pp. 531.

12. Kuester, K., Mittnik, S., Paolella, M. S. (2006). Value-at-risk Prediction: A comparison of Alternative Strategies // Journal of Financial Econometrics. Vol. 4, No. 1, pp. 53-89. doi: 10.1093/jjfinec/ nbj002.

13. Lambadiaris, G., Papadopoulou, L., Skiadopoulos, G. and Zoulis, Y. (2003). VaR: Historical or Simulation? // Risk. Vol. 16, No. 9, pp. 124-126.

14. Mandelbrot, B. (1963). The Variation of Certain Speculative Prices // Journal of Business. No. 36, pp. 394-419. doi: 10.1086/294632.

15. Markovich, N. (2007). Nonparametric Analysis of Univariate Heavy-tailed Data. - Wiley Series in Probability and Statistics, pp. 318. doi: 10.1002/9780470723609.

16. Morgan, J. (1996). Risk Metrics - Technical Document. - New York, pp. 102.

17. NasdaqOMXstatistics. Internetaccess: $<$ http://www. nasdaqomxbaltic.com/market $/$ ?pg=mainlist \&lang=lv $>$, [accessed November 15, 2012].

18. Novak, S. Y. (2011). Extreme Value Methods with Applications to Finance. - Chapman \& Hall/CRC Press.

19. Pflug, G. (2000). Some Remarks on the Valueat-risk and the Conditional Value-at-risk / In, Uryasev, S. (Editor) Probabilistic Constrained Optimization: Methodology and Applications. Kluwer Academic Publishers. Internet access: <http://www.gloriamundi.org/var/pub.html>, [accessed January 14, 2013].

20. Taqqu, M., Bradley, B. (2001). Financial Risk and Heavy Tails. - Elsevier. Princeton and Oxford, pp. 63.

21. Tasche, D. (2000). Conditional Expectation as Quantile Derivative. - Working paper, TU Munchen. <http://www.ma.tum.de/stat/>, [accessed January 23, 2013].

22. Uryasev, S. (2000). Conditional Value-at-Risk: Optimization Algorithms and Applications. Financial Engineering News 2 (3). Internet access: <http://www.gloriamundi.org/var/pub. html $>$, [accessed January 14, 2013].

23. Yamai, Y., Yoshiba, T. (2001). On the Validity of Value-at-risk: Comparative Analyses with Expected Shortfall. Discussion paper 2001-E-4, Institute for Monetary and Economic Studies, Bank of Japan. Internet access: <http://www. gloriamundi.org/var/wps.html >, [accessed January 30,2013$]$.

The paper submitted: April 22, 2013

Prepared for publication: September 1, 2013

\section{Ramona RUPEIKA-APOGA, Roberts NEDOVISS HIPOTETINIO INVESTICIJUু PORTFELIO KIEKYBINIS RIZIKOS VERTINIMAS: BALTIJOS ŠALIŲ ATVEJIS}

\section{S a n t r a u k}

Finansų institucijos, draudimo kompanijos, privatūs investuotojai bei kiti finansų rinkų dalyviai pastaruoju metu susiduria su potencialių sandorių nuostolių vertinimo problema, vis prisimenant pastarojo meto finansų krizę, kaip prastos rizikos valdymo rezultatą. Šiuo metu viena iš svarbiausių rizikai vertinti taikomų priemonių - investicijų portfelio teorija. Rizikos vertinimo metodai buvo sparčiai vystomi, tad svarbu 
perprasti jų taikomumą ir Baltijos šalių akcijų rinkoje.

Mokslinèje literatūroje aprašoma keletas požiūrių i rizikos vertinimą bei pačios rizikos sąvoką. Deja, praktikoje dažniau yra taikomi rizikos vertinimo metodai, kurie nèra pagrịsti teorija. To priežastis, teorinių rizikos vertinimo metodų sudetingumas bei jų trūkumas. Reikètų pažymèti, kad problema kyla dèl tam skirtos programinès įrangos trūkumo, kuri galètų būti naudojama vertinant riziką. Excel programos aplinka negali apdoroti didžiulio duomenų kiekio analizuojant bei vertinant riziką. Be to, statistiniai paketai SPSS ir Eviews neturi rizikos vertinimui skirtos funkcijos. Taigi, siekiant vertinti riziką, turime kurti individualias bei papildomų didelių išlaidų reikalaujančias programas.

Yra daug kliūčių veiksmingam rizikos vertinimui. Visų pirma, nèra vieningo būdo, kaip ịvertinti riziką, nes skirtingi metodai gali duoti skirtingus rezultatus. Antra, kiekvienas metodas turi savų trūkumų.

Pastaruoju metu rizikos vertẻ užima ypatingą vietą finansų sektoriuje - ši sąvoka naudojama beveik visur. VaR yra naudojama rizikos valdymo, finansų kontrolès, finansinès atskaitomybès ir reguliuojamo kapitalo pagal Bazelio komiteto rekomendacijas skaičiavimui.

Klaidingas VaR apskaičiavimas gali sąlygoti tinkamai neįvertintą portfelio riziką, o to pasekoje klaidingų investavimo sprendimų prièmimą, todèl itin svarbu išanalizuoti VaR metodų taikymą Baltijos šalių akcijų rinkos kontekste.

Straipsnyje analizuojama penkių VaR metodų taikymo rezultatai investicinio portfelio valdymo kontekste. Straipsnyje aptariami trys investuotojams svarbūs klausimai, ieškant tinkamų rizikos vertinimo priemonių. Pirma, Baltijos šalių akcijų rinkos investicinio portfelio konstrukcija. Antra, penkių skirtingų VaR rizikos vertinimo metodų empirinis aprobavimas: paremtas istoriniais duomenimis (angl. historical), delta-gama-normalusis (angl. delta-gama-normal), delta-gama-stabilusis (angl. deltagama-stable), Cornish-Fisher ir Monte-Carlo. Trečia, ieškoma tinkamų investavimo horizontų bei stebèjimo laikotarpių, jų dažnumo. Lyginamoji analizè parodè, kad atlikti bandymai duoda panašias rizikos vertinimo vertes ir tinkamo laiko horizonto ir stebejimo laikotarpio pasirinkimas vaidina svarbesni vaidmenį nei taikomo metodo parinkimas. 